\title{
PREDIKSI CURAH HUJAN BULANAN MENGGUNAKAN METODE STATISTICAL DOWNSCALING DI PULAU JAWA DENGAN PEMILIHAN PREDIKTOR BERDASARKAN TRANSPOR UAP AIR
}

\author{
Agus Safrill, Amhar Ulfiana ${ }^{2}$ \\ 1Sekolah Tinggi Meteorologi Klimatologi dan Geofisika \\ Jl. Perhubungan I No 5 Pondok Betung, Tangerang Selatan, Banten \\ 2Balai Besar Wilayah IV Badan Meteorologi Klimatologi dan Geofisika \\ Jl. Abdurrahman Bassalamah No. 4 Makassar Sulawesi Selatan \\ e-mail: agus.safril@stmkg.ac.id
}

\begin{abstract}
Abstrak
Pulau Jawa merupakan bagian dari Benua Maritim dengan karakteristik geografis yang terdiri dari pegunungan dan dataran rendah. Wilayah ini menjadi sentra produksi padi sehingga prediksi curah hujan penting dilakukan untuk dimanfaatkan para petani dalam mengambil kebijakan. Model sirkulasi global (GCM) digunakan dalam prediksi dinamis untuk mendapatkan informasi curah hujan satu bulan, namun resolusinya yang rendah menjadikan model ini tidak dapat digunakan untuk memperoleh informasi dalam skala kecil sehingga diperlukan metode statistical downscaling. Untuk mendapatkan akurasi yang baik diperlukan prediktor yang terkait dengan curah hujan di wilayah Jawa. Pemilihan lokasi kotak grid prediktor didasarkan pada kandungan air mampu curah (precipitable water) di daerah prediksi dan transpor uap air ke wilayah prediksi. Hasil pemilihan kotak grid terdiri dari Laut Cina Selatan, sekitar wilayah Sumatera dan Samudera Pasifik bagian barat. Pemilihan variabel prediktor dilakukan pada 8 parameter unsur cuaca, yaitu angin zonal dan meridional paras 850 dan 200 milibar, suhu udara paras 2-meter dan 850 milibar, tekanan udara pada paras permukaan laut, serta ketinggian geopotensial pada paras 500 milibar. Hasil korelasi prediktor dan prediktan menunjukkan prediktor terpilih terdiri dari beberapa variable (multivariabel). Perbandingan antara hasil prediksi curah hujan model dan observasi menunjukkan RMSE (Root Mean Square Error) terkecil pada kombinasi Laut Cina Selatan dan Sumatera diikuti oleh kombinasi variabel yang lain. Hasil prediksi juga menunjukkan pola hujan prediksi mampu mengikuti pola monsunal dan antar tahunan (ENSO).
\end{abstract}

Kata kunci: Statistical Downscaling, prediktor, transpor uap air, dan curah hujan

\begin{abstract}
Java is an island in the Maritime Continent which geographically consists of mountains and lowlands. This region is a center for rice production so that predictions of rainfall are important to be used by farmers in making policies. The global circulation model (GCM) is used in dynamic predictions to obtain one-month rainfall information, but the low resolution makes this model unable to be used to obtain information on a small scale, so statistical downscaling method are needed. To get good accuracy, predictors related to rainfall in the Jawa region are needed. The selection of predictor grid box locations is based on the precipitable water content in the prediction area and the transport of water vapor to the predicted area. The results of grid box selection consist of the South China Sea, around the Sumatra region and the Western Pacific Ocean. The selection of predictor variables is carried out on 8 weather parameters, namely zonal and meridional winds at 850 and 200 millibars, air temperature at 2-meter and 850 millibars, sea level pressure, and geopotential height at 500 millibars. The results of predictor and predictand correlation show that selected predictors consist of several variables (multivariable). The
\end{abstract}


comparison between the model rainfall prediction results and observations shows the smallest RMSE(Root Mean Square Error) in the combination of the South China Sea and Sumatra followed by other combinations of variables. Prediction results also show that the pattern of rain predictions is able to follow a monsoonal and inter-annual pattern (ENSO).

Keywords: Statistical downscaling, predictor, water vapour transport, dan precipitation

\section{PENDAHULUAN}

Indonesia adalah negara pertanian dan Pulau Jawa merupakan salah satu wilayah sentra produksi padi di Indonesia. Data statistik pada tahun 2015 menunjukkan produksi padi yang berasal dari Pulau Jawa sebesar 39,823,736 ton per tahun dari jumlah produksi nasional $(75,397,840$ ton) atau $53 \%$ dari produksi secara nasional (Badan Pusat Statistik, 2019). Pada sektor pertanian, informasi hujan digunakan untuk pengambilan keputusan, seperti penentuan awal musim tanam. Awal musim hujan ditandai dengan permulaan angin monsun (Moron, et al., 2009). Informasi prediksi hujan yang akurat sangat dibutuhkan untuk menentukan pola tanam. Namun, prediksi hujan seringkali tidak sesuai dengan nilai observasi sehingga dapat mengurangi tingkat kepercayaan pengguna. Adanya perbedaan nilai prediksi dan observasi hujan ini disebabkan oleh tingginya variabilitas curah hujan di suatu wilayah.

Variabilitas curah hujan di Benua Maritim dipengaruhi oleh berbagai fenomena global dan regional tahunan dan antar-tahunan diantaranya monsun, El Nino Southern Oscillation (ENSO), Indian Ocean Dipole (Hendon, 2003; Ashok, et al., 2004; Athoillah, et al., 2007 dan Chang, et al., 2004), La Nina (Nabilah, et al., 2017), maupun pengaruh iklim lokal (Qian, 2008). Akibat dari fenomena ini curah hujan meningkat atau menurun jauh dari normalnya yang menyebabkan gangguan pada bidang pertanian. Sebagai contoh, variabilitas curah hujan antar tahunan (El Nino) menyebabkan pengurangan curah hujan sehingga mempengaruhi produksi padi (Utami, et al., 2017).
Berdasarkan kondisi tersebut maka perlu dikembangkan prediksi curah hujan yang akurat. Salah satu metode prediksi hujan bulanan yang digunakan adalah dengan model numerik yaitu model sirkulasi global (Global Circulations Model GCM) (Goly, 2014). Model ini memiliki kelebihan karena menggunakan pendekatan kopel atmosfer, laut dan daratan (Hastenrath, 1994). Dengan model GCM pola variabilitas curah hujan yang terjadi dapat ditangkap. Hal ini karena menggunakan masukan kondisi iklim terkini (initial condition). Di sisi lain, model GCM memiliki kekurangan yaitu resolusi yang rendah menjadikan model ini tidak dapat memberikan informasi untuk skala detail. Oleh karena itu diperlukan metode statistical downscaling dengan menggunakan prediktor dari keluaran model numerik (GCM) untuk prediksi skala lokal dengan memanfaatkan model statistik (Juneng, et al., 2010).

Hasil akurasi prediksi model menggunakan statistical downscaling ditentukan oleh variabel prediktor yang digunakan untuk prediksi (Masson dan Baddour, 2008). Variabel prediktor yang dipilih harus memiliki kemampuan untuk menangkap sinyal variabilitas iklim baik yang berupa variabilitas tahunan maupun antar tahunan. Model prediksi dengan metode statistical downscaling ini menggunakan kotak prediktor (grid box) untuk menentukan area prediktor (Juneng, et al., 2009). Pemilihan wilayah kotak grid pada wilayah prediktor didasarkan pada keterkaitan secara fisis atmosfer antara variabel prediktor terhadap curah hujan di wilayah prediksi (Tatli, et al., 2004).

Model prediksi statistical downscaling menggunakan berbagai variabel prediktor 
dari keluaran GCM yang menyatakan keterkaitan antara karakteristik fisis atmosfer dengan dengan curah hujan. Variabel prediktor yang terkait erat dengan curah hujan sebagai contoh adalah suhu udara pada ketinggian 500 milibar (T500), kelembaban spesifik pada ketinggian 850 milibar (Q850) dan angin zonal pada ketinggian 850 milibar (U850) (Manzanas, 2017). Penelitian lain di wilayah timur benua Afrika mempertimbangkan prediktor berdasarkan pada fenomena sinoptik (cuaca skala luas) dan proses termodinamika yang mempengaruhi wilayah prediksi. Dari fenomena tersebut didapatkan juga variabel prediktor angin zonal (850 milibar), kelembaban spesifik dan suhu pada lapisan 500 milibar (Nikulin, et al., 2018). Prediktor terpilih juga didasarkan pada variabel yang dapat menangkap pola variabilitas antar tahunan (Osman dan Waleda, 2016)
Hasil prediksi curah hujan bulanan di wilayah pulau Jawa bagian Barat masih terdapat daerah dengan akurasi yang masih rendah terutama di pegunungan (Apriyanal dan Lindawati, 2015). Berdasarkan penelitian tersebut untuk mendapatkan akurasi yang lebih baik perlu digunakan variabel prediktor keluaran GCM yang sesuai untuk Pulau Jawa yang berada di wilayah benua maritim.

\section{DATA DAN METODE Data}

Lokasi penelitian adalah wilayah Pulau Jawa (Gambar 1). Pulau Jawa terdiri dari dataran rendah di utara dan selatan dan dataran tinggi di bagian tengah. Kondisi geografis ini menjadikan awan terkonsentrasi di wilayah pegunungan akibat hujan orografis yang kuat (Qian, 2008).

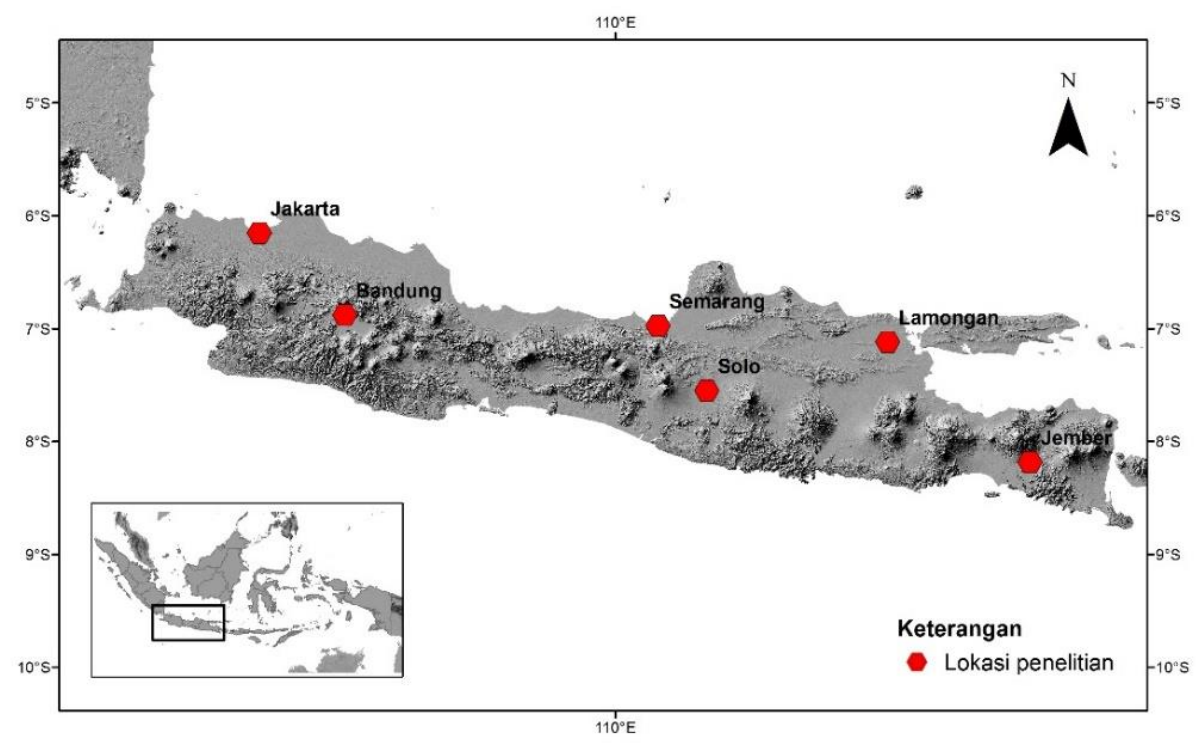

Gambar 1. Lokasi penelitian wilayah Pulau Jawa

Data yang digunakan untuk penelitian terdiri dari dua, yaitu data curah hujan sebagai prediktan (yang diprediksi) dan data variabel prediktor keluaran dari GCM (untuk memprediksi). Data hujan yang digunakan adalah data curah hujan harian tahun 1981-2005 dari 6 stasiun pengamatan hujan di Pulau Jawa yang selanjutnya diolah menjadi curah hujan bulanan yang bersumber dari Badan Meteorologi Klimatologi dan Geofisika dan
Stasiun Klimatologi BMKG Malang yang telah divalidasi oleh Supari (2014). Stasiun hujan terpilih mewakili dataran tinggi dan dataran rendah di bagian barat, tengah, dan timur Pulau Jawa.

Data variabel prediktor digunakan data hindcast (data prediksi pada tahuntahun sebelumnya) dan merupakan sejumlah anggota keluaran model prediksi numerik (ensemble) dari National Centers for Environmental Prediction (NCEP), Amerika 
Serikat yang dikumpulkan oleh Asian Pacific Economic Cooperation Climate Center (APCC) di Busan, Korea Selatan. Data variabel prediktor yang digunakan meliputi angin zonal paras 850 milibar (U850), angin meridional paras 850 milibar (V850), angin zonal paras 200 milibar (U200), angin meridional paras 200 milibar (V200), suhu pada paras 2 meter (T2M), suhu paras 850 milibar (T850), tekanan udara pada paras permukaan laut (SLP) dan ketinggian geopotensial pada paras 500 milibar (Z500). Tiap variabel prediktor memiliki 15 anggota keluaran model GCM. Selanjutnya dari 15 anggota keluaran GCM ini dirata-ratakan sehingga diperoleh nilai rata-rata dari keluaran tersebut. Hasil ratarata keluaran model ini digunakan sebagai input untuk prediksi dengan bantuan statistik (statistical downscaling).

\section{Metode}

Model prediksi menggunakan metode downscaling dengan statistik. Statistical downscaling dilakukan untuk memenuhi kebutuhan informasi skala lokal hingga 5 kilometer. Dengan metode downscaling dapat diperoleh informasi iklim resolusi tinggi dari GCM yang memiliki resolusi rendah (umumnya 150-300 kilometer).

Statistical downscaling merupakan metode penurunan skala menggunakan metode statistik. Pemanfaatan metode statistik antara lain menggunakan metode analisis regresi, jaringan syaraf tiruan (neural network), dan regresi. Dengan metode ini keterhubungan variabel secara statistik digunakan untuk prediksi iklim ke depan. Skema model prediksi statistical downscaling terdiri atas alur seperti yang terlihat pada Gambar 2.

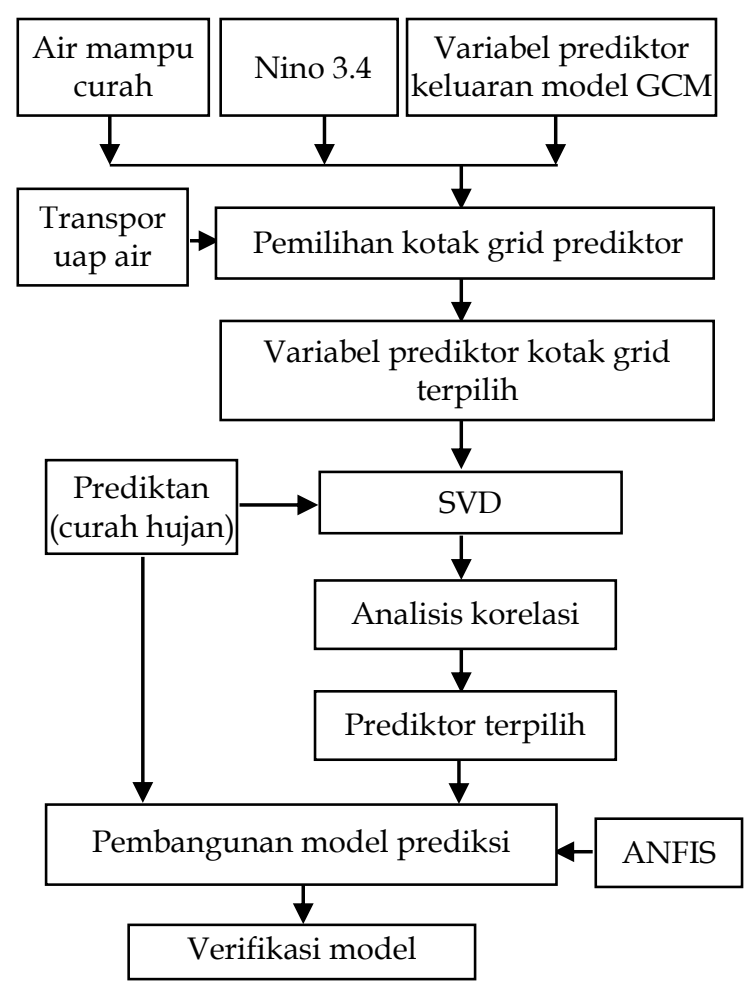

Gambar 2. Pengembangan Model Prediksi Curah Hujan dengan Statistical Dowscaling

Pemilihan kotak grid prediktor didasarkan pada analisis kandungan air mampu curah di wilayah prediktor yang terkait dengan suhu muka laut di wilayah Nino 3.4. Hal ini karena perubahan uap air akibat dinamika suhu di Pasifik Tengah mempengaruhi curah hujan di Benua Maritim (Utami dan Hidayat, 2015). Wilayah dengan korelasi tertinggi dipilih sebagai acuan kotak grid. Selanjutnya 


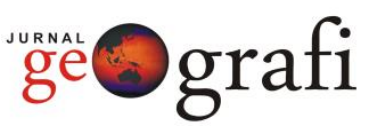

pemilihan kotak grid berdasarkan transpor uap air ke wilayah Pulau Jawa.

Dari kotak grid terpilih selanjutnya dilakukan analisis korelasi antara variabel prediktor dengan curah hujan pada 6 titik stasiun hujan. Analisis korelasi dilakukan dengan SVD matriks (Singular Value Decomposition). Dari hasil analisis korelasi tertinggi diperoleh variabel terbaik.

Variabel terpilih digunakan sebagai variabel bebas (independent variable) dalam model prediksi menggunakan ANFIS (Adaptive Neuro Fuzzy Inference System). Hasil prediksi model kemudian dibandingkan dengan curah hujan observasi untuk verifikasi model.

Variabel prediktor yang dipilih terkait erat dengan curah hujan di stasiun pengamatan. Variabel yang dibangun merupakan hubungan sebab akibat bahwa suhu, tekanan udara, kelembaban udara, dan angin sebagai variabel pembentuk curah hujan. Potensi uap air yang dibawa angin (water vapour transport) (Webster dan Fasullo, 2003) menjadi faktor penentu curah hujan. Uap air yang mengalir ke wilayah prediksi menjadi dasar pemilihan lokasi grid pediktor yang dipilih. Aliran uap air yang menuju wilayah prediktor menjadi dasar bagi pembentukan awan di wilayah tersebut. Potensi ini terutama pada musim hujan (DJF) di mana angin Baratan membawa dampak musim hujan di wilayah Benua Maritim.

Pada saat monsun Asia, terjadi transpor uap air yang bergerak dari Belahan Bumi Utara ke Belahan Bumi Selatan pada bulan Desember, Januari, dan Februari (DJF). Pergerakan uap air dapat diidentifikasi dengan transpor uap air vertikal (integrated moisture transport) dengan mempertimbangkan faktor angin (Webster dan Fasullo, 2003):

$$
B q=\int_{0}^{\infty} q \bar{V}
$$

Keterangan:

$\mathrm{Bq}$ : Transpor uap air vertikal rata-rata

$\overline{\mathrm{V}}$ : Vektor kecepatan angin horizontal pada ketinggian z

Q : Kelembapan spesifik pada ketinggian z

\section{Analisis korelasi}

Analisis korelasi dilakukan dari hasil mode paling dominan analisis SVD (Singular Value Decomposition) dari variabel bebas dan curah hujan (dalam bentuk deret waktu). SVD bidang kopel (pasangan) digunakan untuk melakukan analisis korelasi antara prediktor dan curah hujan. Korelasi dilakukan antara variabel prediktor dengan curah hujan pada skala titik pengamatan curah hujan di 6 titik stasiun. SVD adalah matriks persegi empat dari matriks diagonal. Metode ini mengidentifikasi pasangan-pasangan sepasang kovariansi dari dua bidang spasial, tiap pasangan menjelaskan fraksi kovariansi dari dua bidang tersebut (Bjornson dan Venegas, 1997).

Untuk melaksanakan metode ini, matriks cross covariance disusun berdasarkan waktu dan ruang pada data independen. Kedua matriks tidak harus segi empat dan dapat berbeda dalam hal poin grid, namun waktu dari poin-poin grid tersebut harus sama. Dalam SVD matriks kovariansi silang menghasilkan dua set ortogonal spasial dari vektor singular dan satu set nilai singular yang saling terkait pada pasangan vektor tersebut. Pasangan pola tersebut dinyatakan dengan nilai fraksi terbesar dari SCF (Square Covariance Fraction) antara dua variabel. SCF dihitung untuk tiap pasangan koefisien ekspansi ke-i untuk tiap variabel yang merupakan deret waktu. Korelasi antara koefisien ke-i dari dua variabel menunjukkan kekuatan hubungan dua pola pasangan data tersebut.

Dengan asumsi $\mathrm{S}$ dan $\mathrm{P}$ berpusat kepada waktu, rata-rata waktu $S$ dapat dihilangkan, dibentuk matriks kovarian:

$$
C=S t P
$$

Pada kovariansi matrik yang didapat selanjutnya dibentuk Singular Value Decomposition (SVD), diperoleh matriks $\mathbf{U}$, $\mathbf{V}$ dan diagonal $\mathbf{L}$ maka diperoleh:

$$
\mathrm{C}=\mathrm{ULV}^{\mathrm{T}}
$$


$\mathbf{X}$ adalah vektor singular matriks kolom pada $\mathbf{U}$ dan vektor singular dari $\mathbf{Y}$ matriks dari kolom V. Vektor singular merupakan matriks bujur sangkar dengan determinan. Kolom $\mathbf{U}$ sering disebut dengan pola matriks kiri dan kolom $\mathbf{V}$ pola matriks kanan dan $\mathbf{C}$ merupakan matriks kovarians.

Kandidat variabel bebas yang mempunyai kaitan paling erat dengan curah hujan di daerah prediksi ditetapkan sebagai variabel bebas untuk membentuk persamaan regresi. Nilai korelasi dilambangkan dengan $r$ dengan ketentuan nilai $\mathrm{r}$ tidak lebih dari harga $(-1 \leq \mathrm{r} \leq 1)$. Nilai $r=-1$ berarti korelasi negatif sempurna, nilai 0 artinya tidak ada korelasi dan $r=1$ korelasi positif sempurna. Variabel terpilih selanjutnya digunakan untuk prediksi dengan prediktor multi variabel dari kombinasi wilayah prediktor.

\section{Regresi Berganda berbasis Sistem Cerdas (ANFIS)}

Hasil pemilihan variabel bebas pada kotak grid yang memiliki korelasi tertinggi digunakan untuk masukan prediksi dengan Adaptive Neuro Fuzzy Inference System (ANFIS) (Jang, 1993). Skema prediksi dengan menggunakan ANFIS seperti pada Gambar 3. Langkahlangkah inferensi fuzzy dimulai dari fuzzifikasi, pembentukan aturan fuzzy berdasarkan masukan data $\mu \mathrm{A}_{\mathrm{i}}(\mathrm{x})$, pembobotan $(\mathrm{w})$, pembentukan persamaan least square yang terbobot, dan keluaran akhir berupa curah hujan.

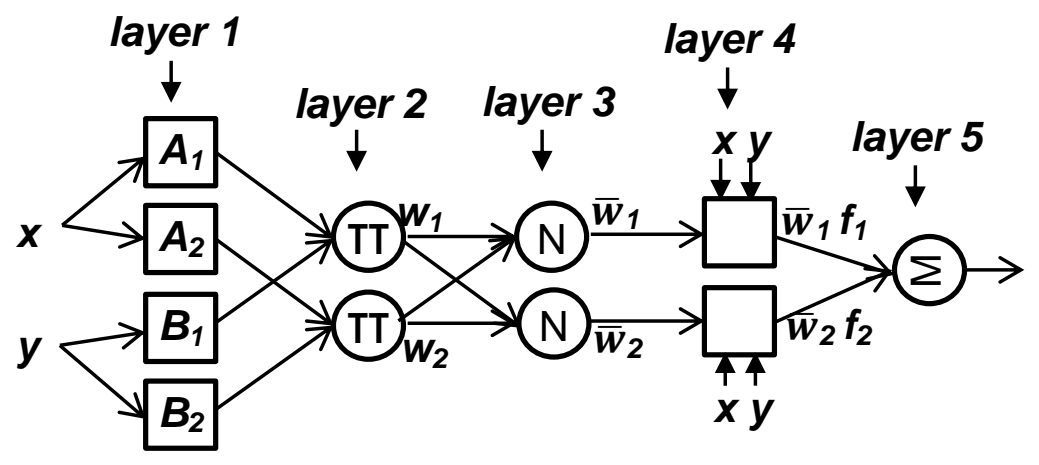

Gambar 3. Struktur ANFIS dari masukan, proses, hingga keluaran

Pada Gambar 3 di atas dilakukan penentuan fungsi keanggotaan $(a, b, c)$ pada persamaan untuk menghitung bobot $\left(\mathrm{w}_{\mathrm{i}}\right)$. Langkah ini untuk mengubah data input menjadi himpunan fuzzy untuk mendapatkan nilai bobot. Secara lebih rinci struktur ANFIS sebagaimana Gambar 3 terbagai pada beberapa layer:

Layer 1, setiap node i pada layer ini sebagai sebuah node kotak dengan suatu fungsi node

$$
O_{i}^{1}=\mu \mathrm{A}_{1}(\mathrm{x})
$$

dengan $x$ adalah masukan terhadap node $\mathrm{i}$ dan $A_{i}$ merupakan label bahasa (besar, kecil, tinggi, rendah dan lain-lain) yang diasosiasikan dengan fungsi ini. Biasanya digunakan $\mu \mathrm{A}_{1}(\mathrm{x})$ dengan bentuk lonceng dengan nilai minimum 0 dan maksimum 1 .

$$
\mu \mathrm{Ai}(\mathrm{x})=\frac{1}{1+\left[\left(\frac{x-c_{i}}{a_{i}}\right)^{2}\right]^{b}}
$$

Layer 2, tiap node di layer ini adalah sebuah node lingkaran dengan label yang merupakan perkalian antara sinyal datang dan mengirimkan dalam bentuk produk keluaran.

$$
W_{i}=\mu A_{i}(x) X \mu B_{i}(y), i=1,2
$$

Layer 3, selanjutnya dari nilai bobot tersebut akan digunakan untuk regresi dengan metode kuadrat terkecil. Tiap node dari layer ini adalah sebuah node lingkaran 


\section{ge Ografi}

dengan label $\mathrm{N}$, derajat pengaktifan ternormalisasi

$$
\bar{w}_{i}=\frac{w_{i}}{w 1+w 2}
$$

Layer 4, menghitung koefisien regresi untuk mendapatkan persamaan regresi dengan pembobotan setiap node i sebagai node segi empat dalam layer ini yaitu :

$$
O_{i}=\bar{w}_{i} f_{i}=\bar{w}_{i}\left(p_{i} x+q_{i} y+r_{i}\right)
$$

Layer 5, selanjutnya keempat persaman tadi digabungkan kembali untuk mendapatkan persamaan regresi dengan pembobotan fuzzy sehingga jumlah total sinyal keluaran sebagai berikut.

$$
\text { Keluaran }=\sum w_{i} f_{i}
$$

\section{Analisis Validasi Model}

Analisis validasi model menggunakan analisis kuantifatif dan kualitatif. Analisis kuantitatif dengan melihat kekuatan hubungan antara hasil prediksi dan observasi serta selisih antara curah hujan prediksi dan observasi (Root Mean Square Error) atau RMSE. Kriteria prediksi rendah bila lebih kecil dari 0,33, sedang bila 0,33-0,66, dan kuat bila lebih dari 0,66. Nilai RMSE bagus bila semakin mendekat nol. Nilai RMSE diperoleh dengan menghitung kuadrat selisih antara observasi $\mathrm{y}_{\mathrm{k}}$ dan prediksi curah hujan $\mathrm{O}_{\mathrm{k}}$ dan $m$ adalah jumlah data dengan persamaan (Wilks, 1995):

$$
R M S E=\frac{1}{m} \sqrt{\sum_{m=1}^{m}\left(y_{k}-o_{k}\right)^{2}}
$$

Analisis kualitatif menggunakan analisis pola curah hujan dengan membandingkan pola curah hujan prediksi dengan observasi dengan pola monsun maupun ENSO. Prediksi curah hujan bagus apabila dapat mengikuti pola variabilitas curah hujan akibat monsun maupun antar tahunan (ENSO).

\section{HASIL DAN PEMBAHASAN}

Kadar Uap Air dan Transpor Uap Air di Wilayah Benua Maritim

Untuk menentukan lokasi (kotak grid) potensi uap air (precipitable water) di benua maritim, pertimbangan pertama menggunakan analisis potensi air mampu curah. Wilayah potensi air mampu curah yang terkait dengan pengaruh variabilitas antar tahunan yang menjadi dasar pemilihan lokasi kotak grid. Pengaruh pertama adalah pengaruh antar tahunan (korelasi Nino 3.4 dengan curah hujan di wilayah Indonesia). Sumber uap air yang terpengaruh ketika suhu permukaan laut di Nino 3.4 berubah. Nino 3.4 (Gambar 4) merupakan wilayah indikator yang sensitif yang mempengaruhi wilayah Indonesia secara telekoneksi.

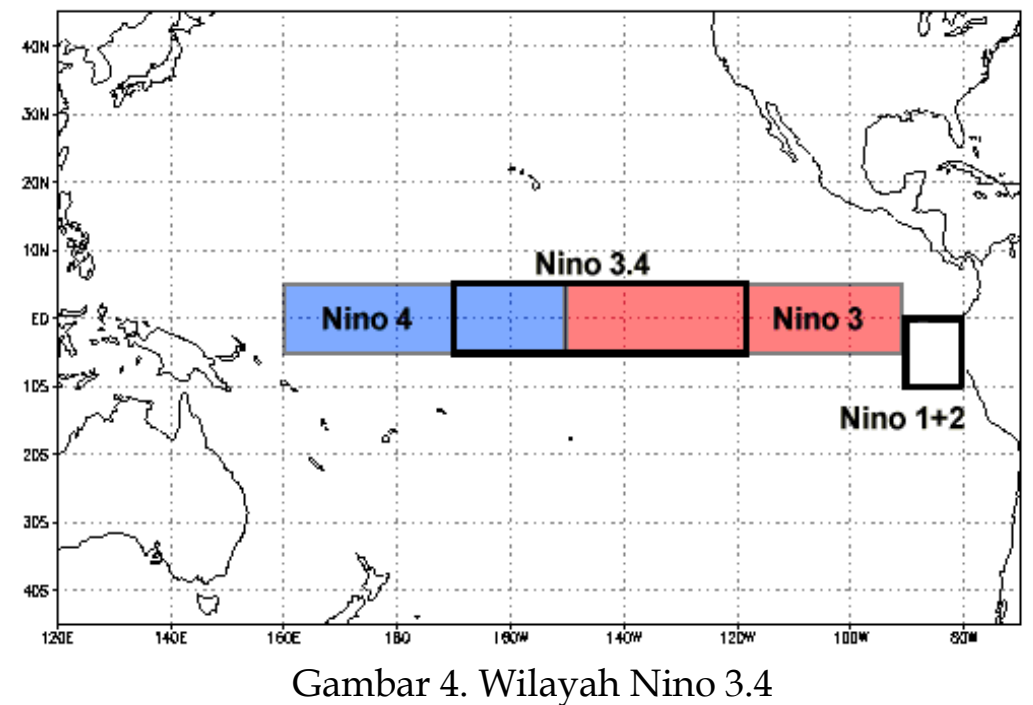

(sumber: https://www.ncdc.noaa.gov/teleconnections/enso/indicators/sst/) 
Pertimbangan ini dilakukan karena wilayah sumber uap air yang menjadi wilayah potensi kotak grid terpilih karena ada keterkaitan erat dengan suhu muka laut di wilayah Pasifik Tengah seperti pada Gambar 5. Suhu muka laut di wilayah Pasifik ini mempengaruhi karakteristik curah hujan di wilayah Benua Maritim (Chang, et al., 2004; Tjasyono, et al. 2008). Selain itu suhu muka laut lokal di sekitar pulau di Benua Maritim juga mempengaruhi curah hujan (Lee, 2015). Precipitable water ini adalah kandungan air yang berpotensi menjadi hujan untuk wilayah dipengaruhi oleh ENSO. Wilayah ini akan menjadi sumber uap air ke wilayah Jawa yang dibawa oleh angin monsun. Wilayah tersebut dimulai dari Pasifik Barat, Laut Cina Selatan, dan Sumatera, di mana berkurang dan meningkatnya kadar uap air ini akan mempengaruhi wilayah Pulau Jawa. Pada saat ENSO, kandungan uap air berubah menjadi sedikit dan membawa dampak musim kering yang panjang di Jawa. Korelasi yang tinggi dengan sumber variabilitas $(-0,60)$ di Laut Cina Selatan dan Pasifik Barat begitu juga dengan wilayah perairan sekitar Sumatera $(>0,60)$.

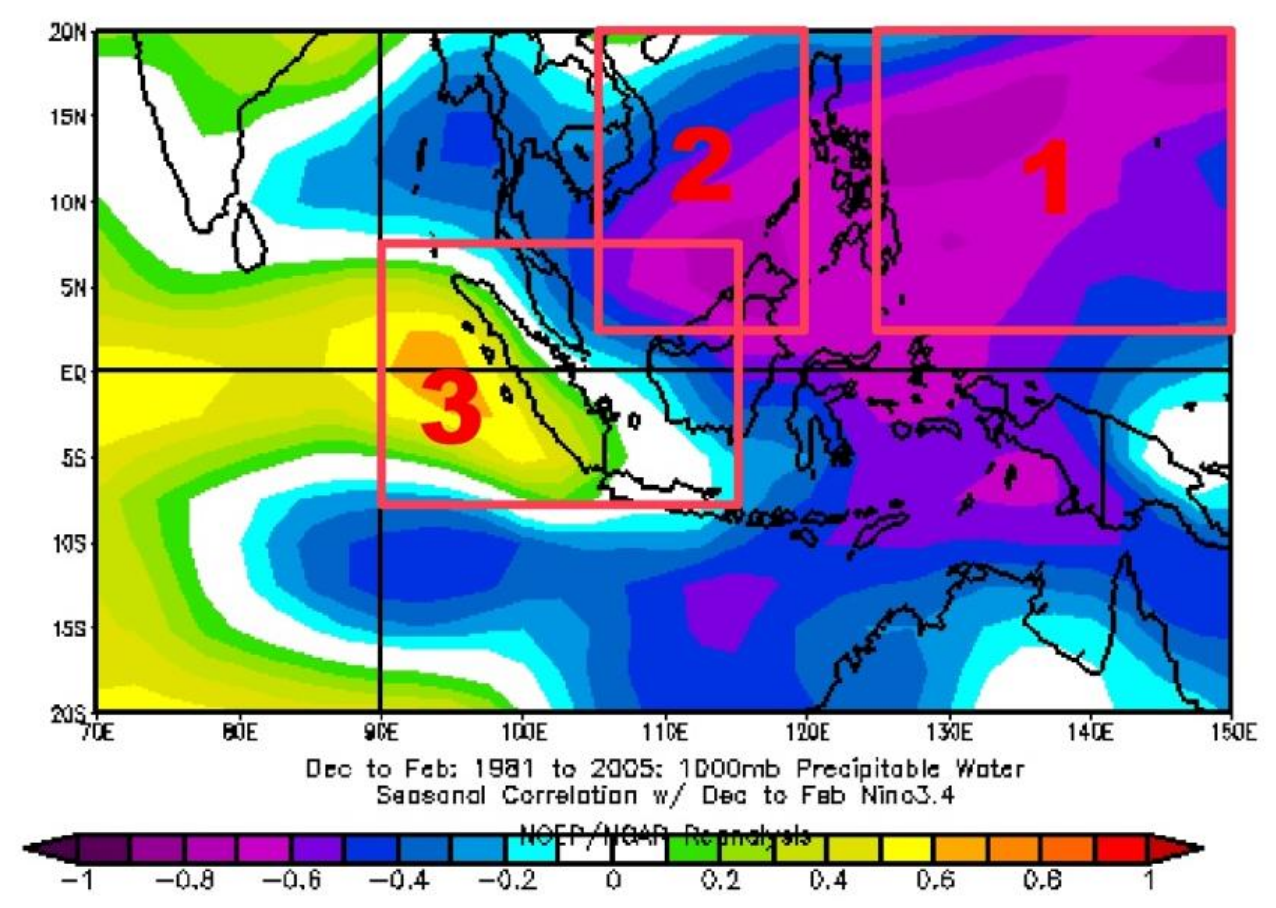

NOAS/ESRL Phraioal Seisnces Di

Gambar 5. Korelasi Air Mampu Curah (precipitable water) dengan Suhu Muka Laut di Pasifik Tengah dan Lokasi Kotak Prediktor

Berdasarkan kondisi tersebut maka diperlukan faktor yang membawa uap air ke wilayah Benua Maritim, yaitu transpor uap air oleh angin (Batubara, 2017). Pertimbangan kedua yaitu pengaruh yang kedua adalah wilayah monsun. Transpor uap air menunjukkan pasokan uap air (biru tua) yang menjadi sumber di Pulau Jawa adalah berasal dari Pasifik Barat (kotak grid 1), Laut Cina Selatan (kotak grid 2), Teluk Benggala (kotak grid 3), sekitar Pulau Sumatera (kotak grid 4), dan sekitar Pulau
Jawa (kotak grid 5) seperti pada Gambar 5. Transpor uap air pada periode DJF menunjukkan $300-400 \mathrm{~kg} / \mathrm{m}$ det-1 ${ }^{1}$ di Pasifik Barat dan Laut Cina Selatan dan 200-300 $\mathrm{kg} / \mathrm{m}_{\text {det- }}{ }^{1}$ di perairan sekitar Sumatera.

Dari hasil kedua analisis tersebut diperoleh lokasi kotak grid prediktor lain yang secara fisis dan dinamika atmosfer mempengaruhi curah hujan di Pulau Jawa yang meliputi.

1. Pasifik Barat (PBRT) $\left(125^{\circ} \mathrm{BT}-150^{\circ} \mathrm{BT}\right.$, $\left.2,5^{\circ} \mathrm{LU}-20^{\circ} \mathrm{LU}\right)$ 
2. Laut China Selatan (LCS) $\left(105^{\circ} \mathrm{BT}-120^{\circ}\right.$ $\left.\mathrm{BT}, 2,5^{\circ} \mathrm{LU}-20^{\circ} \mathrm{LU}\right)$
3. Sumatera (SMT) dan Samudera Hindia bagian Barat $\left(90^{\circ} \mathrm{BT}-115^{\circ} \mathrm{BT}, 7,5^{\circ} \mathrm{LS}-\right.$ $\left.7,5^{\circ} \mathrm{LU}\right)$

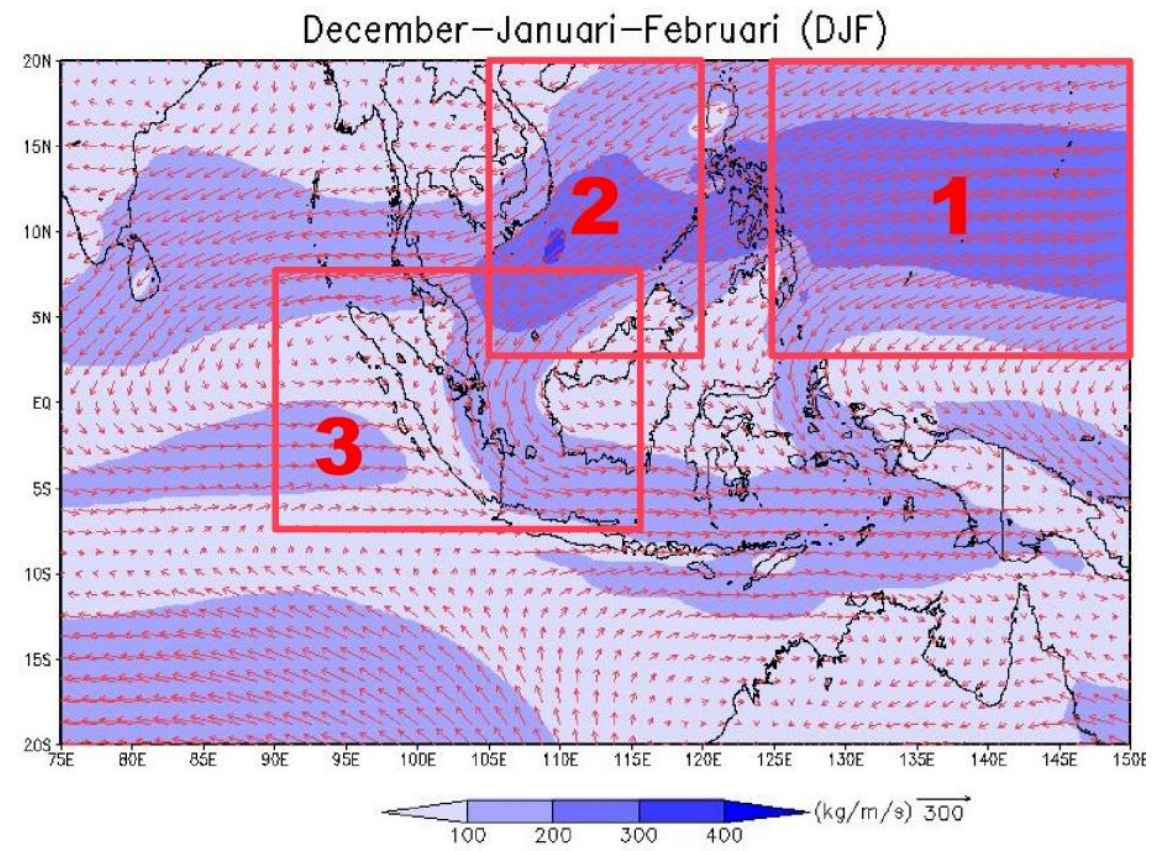

Gambar 5. Transpor Uap Air di Wilayah Benua Maritim Pada Kotak Grid 1 (Laut Cina Selatan), Kotak grid 2 (Laut Cina Selatan), dan Kotak Grid 3 (Sumatera dan Sekitarnya)

\section{Korelasi Prediktor dan Curah Hujan}

Hasil korelasi menunjukkan variabel terpilih prediktor untuk Pulau Jawa terdiri dari beberapa variabel (multivariabel). Variabel yang paling dominan adalah U850, T2M diikuti oleh variabel prediktor lainnya. Hasil korelasi antara variabel prediktor kotak grid 1 (Laut
Cina Selatan) dan curah hujan di Pulau Jawa menunjukkan umumnya korelasi di atas 0,5 (kuat) (Tabel 1). Hasil variabel prediktor dengan nilai korelasi tertinggi selanjutnya digunakan sebagai kandidat prediktor untuk input regresi.

Tabel 1. Korelasi Variabel Atmosfer Kotak Grid Laut Cina Selatan dan Curah Hujan di Pulau Jawa

\begin{tabular}{|c|c|c|c|c|c|c|c|}
\hline No & Variabel & Jakarta & Bandung & Semarang & Solo & Lamongan & Jember \\
\hline 1 & U850 & 0,60 & 0,55 & 0,65 & 0,73 & 0,71 & 0,76 \\
\hline 2 & V850 & 0,56 & 0,49 & 0,64 & 0,69 & 0,70 & 0,73 \\
\hline 3 & U200 & 0,56 & 0,56 & 0,50 & 0,65 & 0,68 & 0,63 \\
\hline 4 & V200 & 0,59 & 0,52 & 0,64 & 0,73 & 0,75 & 0,75 \\
\hline 5 & $\mathrm{~T} 2 \mathrm{M}$ & 0,52 & 0,47 & 0,61 & 0,66 & 0,68 & 0,72 \\
\hline 6 & $\mathrm{~T} 850$ & 0,47 & 0,42 & 0,57 & 0,59 & 0,60 & 0,65 \\
\hline 7 & SLP & 0,55 & 0,56 & 0,60 & 0,69 & 0,66 & 0,73 \\
\hline \multirow[t]{3}{*}{8} & $\mathrm{Z} 500$ & 0,35 & 0,39 & 0,33 & 0,45 & 0,49 & 0,38 \\
\hline & Kor. Tertinggi & 0,60 & 0,56 & 0,65 & 0,73 & 0,75 & 0,76 \\
\hline & Terpilih & U850 & SLP & U850 & U850 & V200 & U850 \\
\hline
\end{tabular}

Sumber: Hasil Penelitian (2018) 
Hasil korelasi antara variabel prediktor kotak grid yang lain (Laut Cina Selatan dan Sumatera) dan curah hujan di Pulau Jawa menunjukkan umumnya juga korelasi di atas 0,60 (kuat) (Tabel 2). Variabel prediktor terpilih (korelasi tertinggi) pada umumnya bervariasi (multivariabel) dengan variabel U850 yang dominan. Karakteristik curah hujan penjelasan mengapa U850 dominan karena dari analisis spasial menujukkan pola U850 terkait erat dengan suhu muka laut di Pasifik Tengah sebagaimana pada Gambar 6.

Tabel 2. Prediktor dengan Nilai Korelasi Tertinggi Antara Variabel Prediktor dan Curah Hujan (diurutkan Pasifik Barat, Laut Cina Selatan dan Sumatera)

\begin{tabular}{ccccccccc}
\hline \multirow{2}{*}{ No } & $\begin{array}{c}\text { Kotak } \\
\text { Grid }\end{array}$ & Kor./var & Jakarta & Bandung & Semarang & Solo & Lamongan & Jember \\
\hline \multirow{2}{*}{1} & \multirow{2}{*}{ Sumatera } & Korelasi & 0,62 & 0,57 & 0,69 & 0,77 & 0,76 & 0,79 \\
\cline { 3 - 9 } & Variabel & U200 & SLP & SLP & SLP & SLP & SLP \\
\hline \multirow{2}{*}{2} & \multirow{2}{*}{ LCS } & Korelasi & 0,62 & 0,61 & 0,77 & 0,76 & 0,70 & 0,72 \\
\cline { 3 - 9 } & Variabel & U850 & SLP & U850 & U850 & U850 & U850 \\
\hline \multirow{2}{*}{3} & $\begin{array}{c}\text { Pasifik } \\
\text { Barat }\end{array}$ & Korelasi & 0,60 & 0,52 & 0,60 & 0,70 & 0,69 & 0,70 \\
\cline { 2 - 8 } & Variabel & U850 & T2M & U850 & U850 & U850 & U850 \\
\hline
\end{tabular}

Sumber: Hasil Penelitian (2018)

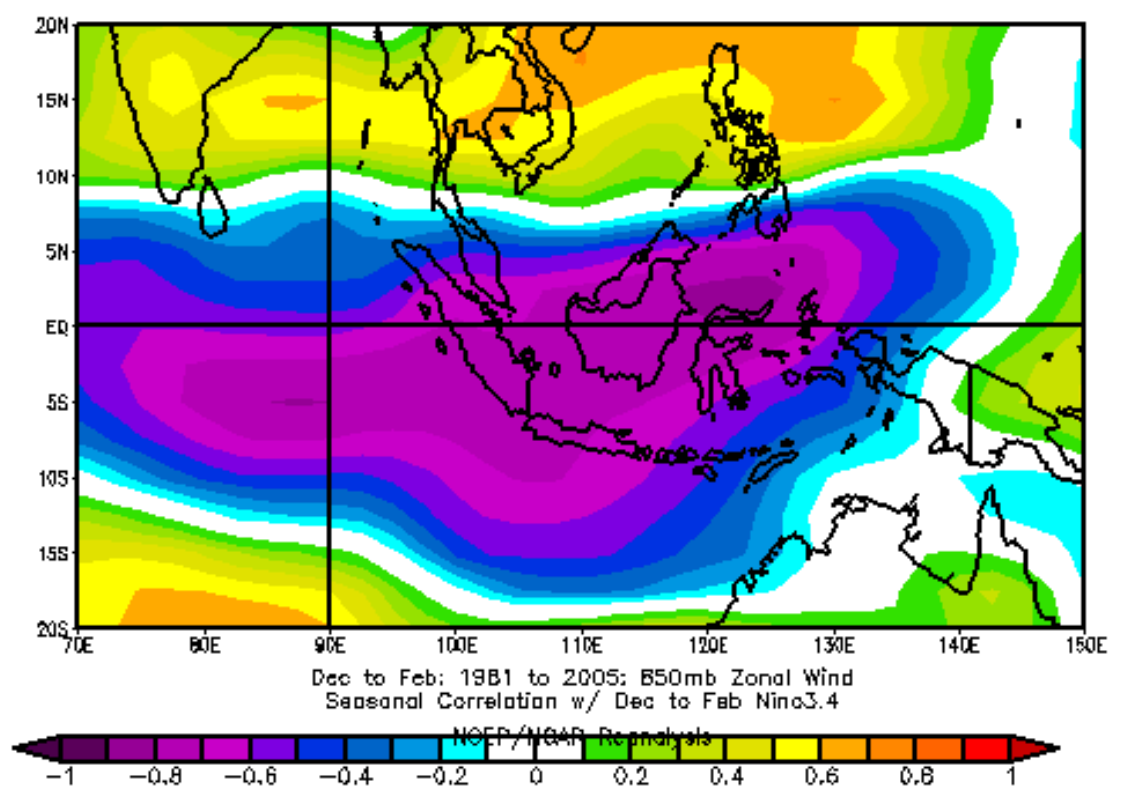

NosivesRL Phyaical Sciences Divieion

Gambar 6. Korelasi Angin Zonal (U850) Observasi dengan Suhu Muka Laut di Pasifik Tengah

Kombinasi Kotak Grid Prediktor (Grid Box)

Kombinasi kotak grid ini menggambarkan uap air yang masuk ke wilayah Jawa. Kombinasi kotak grid sekitar Laut Cina Selatan dan kotak grid wilayah Sumatera yang memberikan pasokan uap air ke wilayah Pulau Jawa. Begitu juga dengan kombinasi yang lain kotak grid wilayah Pasifik Barat dan kotak grid wilayah Laut Cina Selatan dan seterusnya. Laut Cina Selatan dan Pulau Sumatera sebagai wilayah yang paling dekat sumber uap air di wilayah Jawa. Kombinasi kotak grid prediktor ketiga wilayah tersebut disajikan pada Tabel 3. 
Tabel 3. Kombinasi Kotak Grid Prediktor

\begin{tabular}{cc}
\hline No & Kombinasi Kotak Grid \\
\hline 1 & Laut Cina Selatan - Sumatera \\
2 & Pasifik Barat - Laut Cina Selatan \\
3 & Pasifik Barat - Sumatera \\
\hline
\end{tabular}

Sumber: Hasil Penelitian (2018)

\section{Validasi Model Prediksi Curah Hujan}

Analisis Korelasi dan RMSE

Hasil analisis korelasi antara hasil prediksi dan curah hujan observasi menunjukkan umumnya relatif kuat $(>0,66)$. Kemampuan prediksi dengan kategori sedang ditunjukkan oleh wilayah Jakarta. Nilai RMSE untuk kombinasi kotak grid Laut Cina Selatan dan sekitar Pulau Sumatera menunjukkan RMSE yang lebih kecil. Hal ini menunjukkan kemampuan prediktor untuk wilayah ini, transpor uap air yang memiliki hubungan erat dengan curah hujan di wilayah prediksi sehingga mempunyai akurasi yang lebih tinggi (Tabel 4).

\section{Pola Curah Hujan}

Pada analisis pola, pola curah hujan prediksi dibandingkan dengan pola hujan observasi. Pola dibandingkan pada saat terjadinya monsun maupun ENSO. Pada awal tahun 2003 El Nino terjadi dengan kategori lemah. Nilai indeks El Nino pada awal hingga Agustus menunjukkan nilai positif $(>0,5)$ dan La Nina pada akhir 2003 seperti pada Gambar 7. Adapun pola lain adalah pola musiman (monsun) (Aldrian dan Susanto 2003; Chang, et al., 2004).

Tabel 4. Analisis Kemampuan Prediksi dengan Nilai RMSE dan Korelasi (r) dengan Data Independen 2003-2005 Pada Kombinasi Kotak Grid

\begin{tabular}{|c|c|c|c|c|c|c|c|c|}
\hline No & $\begin{array}{c}\text { Kombinasi Kotak } \\
\text { Grid }\end{array}$ & & Jakarta & Bandung & Semarang & Solo & Lamongan & Jember \\
\hline \multirow{2}{*}{1} & \multirow{2}{*}{$\begin{array}{l}\text { Laut Cina Selatan - } \\
\text { Sumatera }\end{array}$} & RMSE & 86 & 57 & 77 & 110 & 43 & 78 \\
\hline & & $\mathrm{R}$ & 0,49 & 0,66 & 0,68 & 0,69 & 0,84 & 0,81 \\
\hline \multirow{2}{*}{2} & \multirow{2}{*}{$\begin{array}{l}\text { Pasifik Barat - Laut } \\
\text { Cina Selatan }\end{array}$} & RMSE & 88 & 59 & 75 & 115 & 44 & 81 \\
\hline & & $\mathrm{R}$ & 0,46 & 0,65 & 0,73 & 0,64 & 0,84 & 0,81 \\
\hline \multirow{2}{*}{3} & \multirow{2}{*}{$\begin{array}{l}\text { Pasifik Barat - } \\
\text { Sumatera }\end{array}$} & RMSE & 86 & 61 & 78 & 115 & 43 & 79 \\
\hline & & $\mathrm{R}$ & 0,52 & 0,64 & 0,68 & 0,64 & 0,84 & 0,80 \\
\hline & RMSE Terkecil & & 86 & 57 & 75 & 110 & 43 & 78 \\
\hline
\end{tabular}

Sumber: Hasil Penelitian (2018)

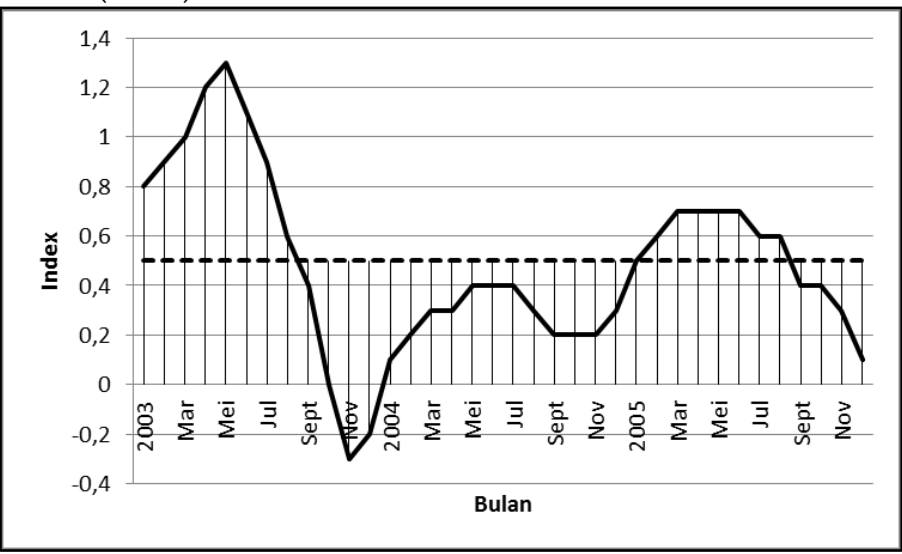

Gambar 7. Indeks Nino 3.4 
Secara umum, curah hujan dapat memperlihatkan pola monsun, dimana curah hujan rendah umumnya terjadi pada awal Mei hingga September dan curah hujan tinggi pada November hingga

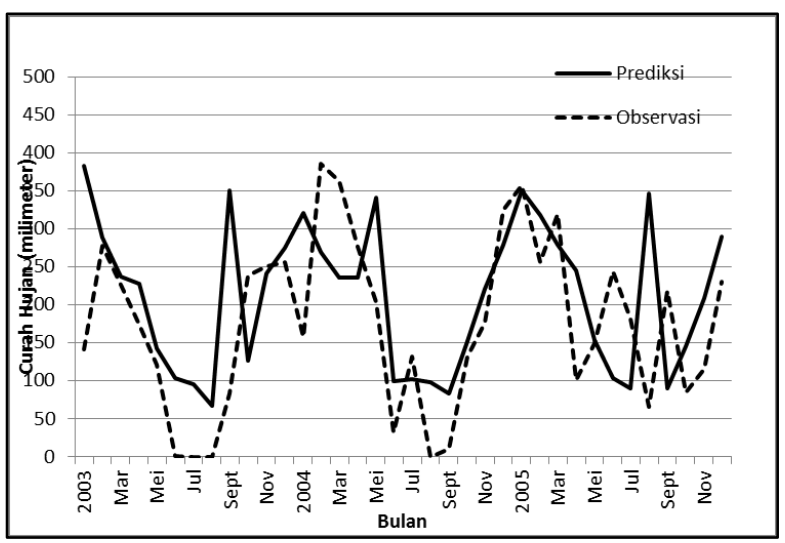

Jakarta
Februari-Maret. Wilayah yang mewakili bagian barat Pulau Jawa yaitu Jakarta dan Bandung menunjukkan hasil prediksi curah hujan yang polanya dapat mengikuti pola curah hujan observasi (Gambar 8).

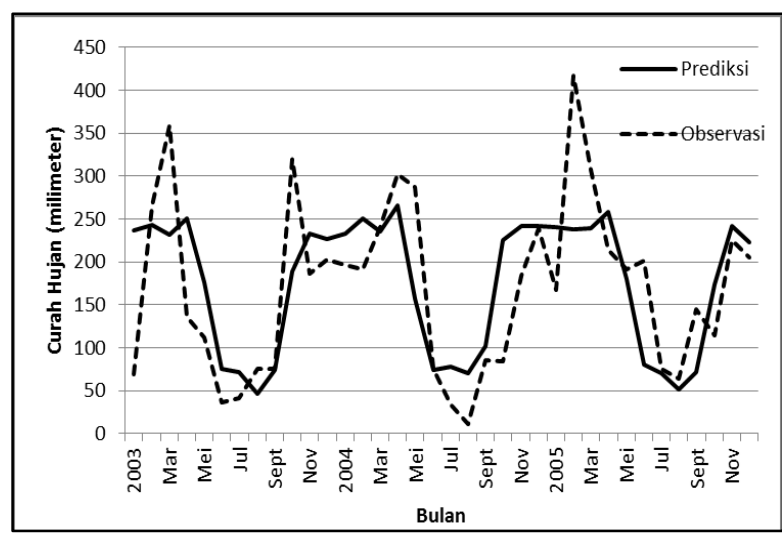

Bandung

Gambar 8. Perbandingan Hasil Prediksi Curah Hujan dan Curah Hujan Observasi di Pulau Jawa Bagian Barat (Jakarta dan Bandung)

Seperti halnya Jawa bagian Barat, wilayah pantai utara) Semarang dan pegunungan (Surakarta) juga menunjukkan hasil curah hujan prediksi dapat mengikuti

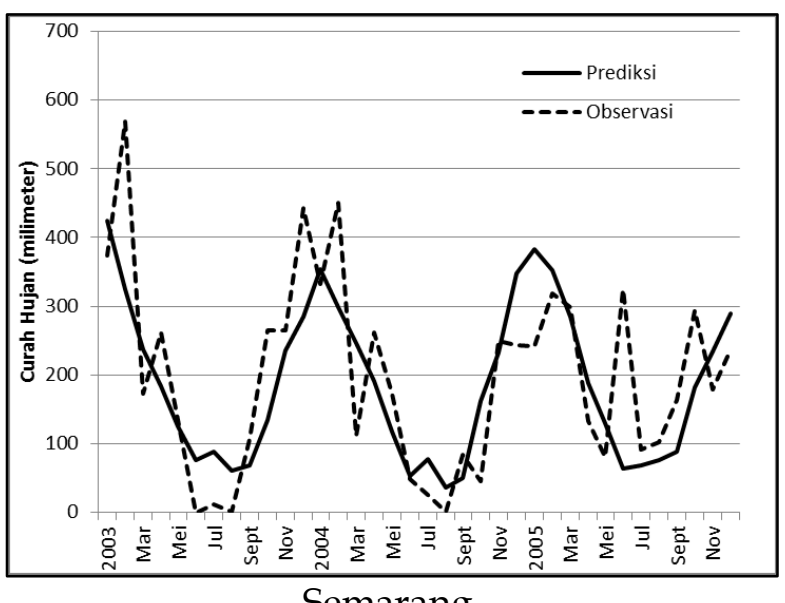

pola curah hujan obsevasi. Pada kejadian El Nino 2003-2004, pola antar tahunan juga dapat diikuti oleh curah hujan observasi seperti pada Gambar 9.

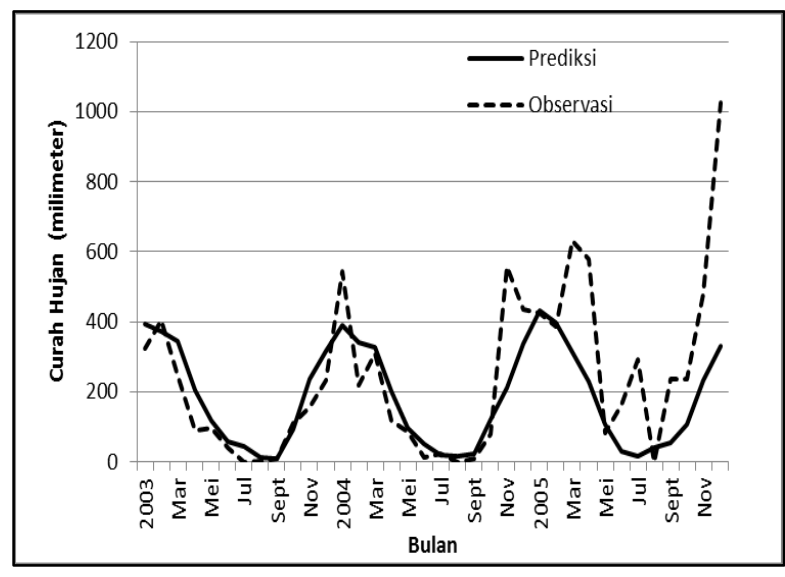

Solo

Gambar 9. Perbandingan Hasil Prediksi Curah Hujan dan Curah Hujan Observasi di Pulau Jawa bagian Tengah (Semarang dan Solo)

Pada wilayah yang mewakili Jawa bagian Timur (Lamongan dan Jember) prediksi curah hujan juga dapat menunjukkan pola monsun. Pada variabilitas antara tahunan (El Nino) pola prediksi dapat mengikuti pola hujan observasi dengan curah hujan umumnya $<50$ milimeter/bulan seperti pada Gambar 10. 


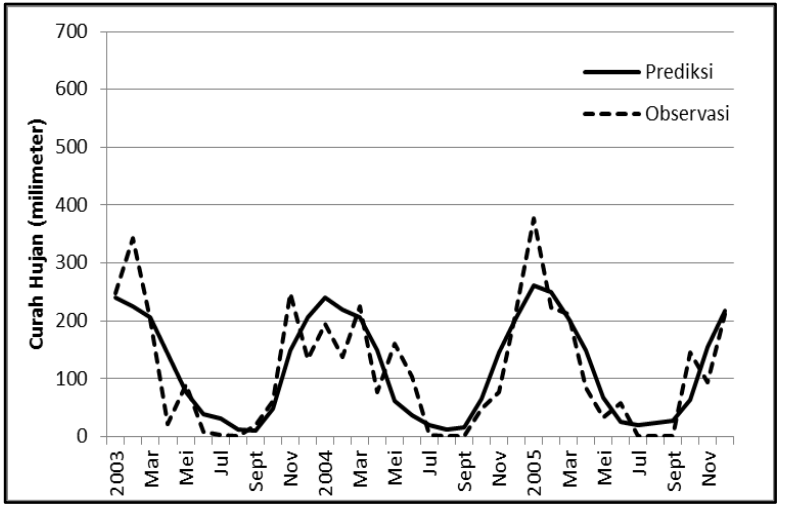

Lamongan

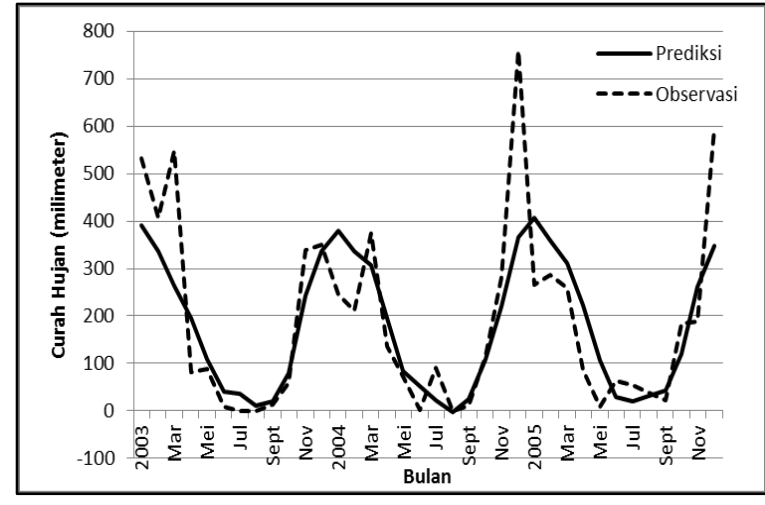

Jember

Gambar 10. Perbandingan Hasil Prediksi Curah Hujan dan Curah Hujan Observasi di Pulau Jawa Bagian Timur (Lamongan dan Jember)

\section{Diskusi}

Karakteristik fisis atmosfer yang terkait erat dengan wilayah prediksi menjadi dasar pemilihan kotak grid prediktor. Pemilihan ini berasal dari kotak grid di luar wilayah prediksi. Karakteristik pergerakan uap air ke wilayah prediksi menjadi dasar utama pemilihan prediktor. Keterkaitan ini diperoleh dari uap air lokal di wilayah terdekat dengan Pulau Jawa. Lokasi yang dekat dengan wilayah ini memberikan suplai uap air internal ke wilayah prediksi. Adapun sumber uap air dari eksternal diperoleh dari transpor uap air dari sekitar Samudera Hindia (Pulau Sumatera), Laut Cina Selatan, dan Pasifik Barat Filipina. Kombinasi sumber uap air eksternal ini menjadikan wilayah kotak prediktor memiliki korelasi yang erat dengan curah hujan di daerah Jawa.

Ketiga wilayah ini memiliki kaitan erat dengan suhu muka laut di wilayah Samudera Pasifik bagian tengah. Hal ini juga mempengaruhi anomali transfer uap air ke wilayah Jawa akibat melemahnya sirkulasi Walker akibat pengaruh ENSO. Beberapa parameter yang dominan adalah angin zonal pada 850 milibar (U850). Kondisi ini disebabkan pengaruh monsun yang kuat ke wilayah Pulau Jawa pada bulan DJF (Desember-Januari-Februari) dengan menguatnya angin Baratan yang banyak membawa uap air.

Hasil prediksi menunjukkan pola hujan prediksi dari model dapat menangkap pola hujan maksimum dan minimum kecuali Bandung. Fenomena global yang berpengaruh dapat dilihat dari kemampuan model yang mempunyai korelasi yang kuat $(>0,66)$. Bandung sebagai wilayah yang dikelilingi oleh pegunungan menjadikan wilayah ini dipengaruhi oleh karakteristik lokal. Angin lembah dan gunung diduga menjadikan wilayah ini memiliki variabilitas curah hujan yang tinggi dibandingkan dengan daerah lain di pulau Jawa. Variabel prediktor lokal dalam hal ini diperlukan untuk meningkatkan kemampuan prediksi di wilayah Bandung.

\section{KESIMPULAN}

Pemilihan wilayah kotak grid prediktor berdasar air mampu curah dan transpor uap air memberikan kaitan yang erat antara variabel prediktor dan curah hujan di di daerah Jawa sehingga layak digunakan sebagai kandidat prediktor. Dari gabungan kombinasi kotak grid prediktor wilayah Laut Cina Selatan - Pulau Sumatera dan dengan wilayah prediksi mempunyai akurasi yang lebih baik dibandingkan dengan kotak grid yang letaknya jauh (Pasifik Barat), ditunjukkan oleh nilai RMSE yang lebih kecil. Kemampuan prediksi curah hujan di wilayah pantai utara dan pegunungan dengan tingkat korelasi yang tinggi dan RMSE yang rendah untuk wilayah Jawa bagian Barat-Tengah dan Timur. Secara spasial hasil prediksi di bagian pegunungan dan dataran rendah menunjukkan hasil yang baik dengan 
korelasi di atas 0,6, kecuali Jakarta di atas 0,5 . Selanjutnya secara temporal, analisis hasil curah hujan prediksi dengan curah hujan observasi dapat menangkap pola monsun dan El Nino.

\section{DAFTAR PUSTAKA}

Aldrian, E. dan Susanto, R. D. (2003). Identification of Three Dominant Rainfall Regions within Indonesia and Their Relationship to Sea Surface Temperature. Int. J. Climatol., 23, 1435-1452.

Apriyanal. Y. dan Lindawati. (2015), Aplikasi Model Prediksi Curah Hujan Pada Dua Sentra Produksi Padi Di Jawa Barat, Informatika Pertanian, Vol. 24, No.2, 149 - 156.

Ashok, K., Zhaoyong, Saji, N.H dan Yamagata, T. (2004). Individual and Combined Influences of ENSO and the Indian Ocean Dipole on the Indian Summer Monsoon. Journal Of Climate, 17, 3141-3155.

Athoillah, I., Sibarani, R. M., Doloksaribu, D. E. (2017). Analisis Spasial El Nino Kuat Tahun 2015 dan La Nina Lemah Tahun 2016 (Pengaruhnya terhadap Kelembapan, Angin dan Curah Hujan di Indonesia. Jurnal Sains \& Teknologi Modifikasi Cuaca, 18(1), 33 - 41.

BPS, Badan Pusat Statistik (2019). https://www.bps.go.id/linkTableDina mis/view/id/865 [17 Januari 2019]

Batubara, P.N.B. (2017),, The Impact Of Meridonal Wind To Themoisture Transport And Weather Formation In West Indonesia On February Prosiding Seminar Nasional Fisika Vol VI, Oktober p-ISSN: 2339-0654, e-ISSN: 2476-9398,

DOI:doi.org/10.21009/03.SNF2017.02. EPA.06

Björnsson, H. dan Venegas, S. A. (1997). A Manual for EOF and SVD Analyses of Climatic Data. Montreal: Department of Atmospheric and Oceanic Sciences and
Centre for Climate and Global Change Research, Mc Gill University) p 23

Chang, C.P., McBride, J., dan Liu, C. (2004), Annual Cycle of Southeast Asia-Maritim Continent Rainfall and the Asymmetric Monson Transition. Journal of Climate, 18, 287-301.

Chang, C. P., Wang, Z., Ju, J., dan Li, T. (2004). On The Relationship between Western Maritim Continent Monsoon Rainfall and ENSO during Northern Winter. Journal of Climate, 17, 665-672.

Goly, A. (2014). Development and Evaluation of Statistical Downscaling Models for Monthly Precipitation, Earth Interactions. Volume 18, Paper No. 18, Page 1

Hastenrath. (1994). Recent Advances in Tropical Climate Prediction. Journal of Climate, 8, 1519-1532.

Hendon. (2003). Indonesian Rainfall Variability: Impacts of ENSO and Local Air-Sea Interaction. Journal of Climate, 16, 1775-1789.

Jang, J.S.R. (1993). ANFIS: Adaptive-NetworkBasec Fuzzy Inference System. IEEE Transactions of Sytems, Man, and Cybernetic, 23(3), 1993.

Juneng, L., Tangang, F. T., Kang, H., Lee, W. J. dan Seng, Y. K. (2010). Statistical Downscaling Forecasts for Winter Monsoon Precipitation in Malaysia, Using Multimodel Output Variables. J. Clim., 23, 17-27.

Lee, H.S. (2015). “ General Rainfall Patterns in Indonesia and the Potential Impacts of Local Seas on Rainfall Intensity", Water, 7, p 1751-1768; doi:10.3390/w7041751, I SSN 2073-4441

Manzanas, R. (2017). Assessing the suitability of statistical downscaling approaches for seasonal forecasting in Senegal 


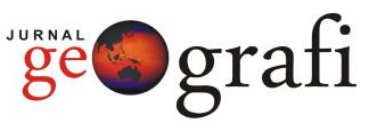

Atmospheric Science Letters Atmos. Sci. Let. 18: 381-386, DOI: 10.1002/asl.767

Moron, V., Robertson, A. W., dan Boer, R. (2009). Spatial Coherence and Seasonal Predictability of Monsoon Onset over Indonesia. Journal of Climate, 22, 840-850.

Masson, J. S. dan Baddour O. (2008). Statistical Modeling, Seasonal Climate : Forecasting and Managing Risk, 163-200

Osman, Y. Z., dan Waleda E. A. (2016). Improving Accuracy of Dowscaling Rainfall by Combining Prediction of Different Statistical Downscale Model, Water science, 30, 61-75

Nabilah, F., Prasetyo, Y., dan Sukmono. (2017). Analisis Pengaruh Fenomena El Nino Dan La Nina Terhadap Curah Hujan Tahun 1998 - 2016 menggunakan Indikator Oni (Oceanic Nino Index) (Studi Kasus : Provinsi Jawa Barat), Jurnal Geodesi Universitas Diponegoro.

Nikulin, G., Asharaf, S., Magariñoc, M.E, Calmantie, S., Cardosod, R. M., Bhendg, J., Fernándezc, J., Fríasc, M. D., Fröhlichb, K., Frühb, B. , Garcíac, S. H., Manzanasf, R., Gutiérrezf, J. M, Hanssona, U., Kolaxa, M., Linigerg, M.A., Soaresd, P. M. M, Spirigg, C., Tomed, R., Klaus Wysera K. (2018). Dynamical and statistical downscaling of a global seasonal hindcast in eastern Africa, Climate Services, 9, 72-85

Qian, J. H. (2008). Why Precipitation is Mostly Concentrated over Islands in the Maritime Continent. Journal of the Atmospheric Sciences, 65b, 1428-1441.

Supari. (2014). Spatiotemporal Characteristics of Extreme Rainfall Events Over Java Island, Indonesia (Case: East Java Province),Fakultas Geografi, Universitas Gadjah Mada.

Tatli Hasan, Dalfes, H. Nu“ Zhet B. Mentes, dan S, Sibel A. (2004): Statistical
Available at http://jurnal.unimed.ac.id/2012/index.php/geo e-ISSN: 2549-7057 | p-ISSN: 2085-8167

Downscaling Method For Monthly Total Precipitation Over Turkey, International Journal of Climatolology, 24: 161-180.

Tjasyono, B. H. K., Lubis, A., Junaeni, I., Ruminta dan Harijono, S. W. B. (2008). Dampak Variasi Temperatur Samudera Pasifik dan Hindia Ekuatorial Terhadap Curah Hujan di Indonesia. Jurnal Sains Dirgantara, 5, 83-95.

Utami, A.W, Jamhari, dan Hardyastuti, S. (2017). El Nino, La Nina, dan Penawaran Pangan di Jawa, Indonesia Jurnal Ekonomi Pembangunan, 12(2), 257-271.

Utami, M. N. R. dan Hidayat, R. (2015). Influences of IOD and ENSO to Indonesia Rainfall Variability: Role of AtmosphereOcean Interaction in the Indo-Pacific Sector. The 2nd International Symposium on LAPAN-IPB Satellite for Food Security and Environmental Monitoring LISAT-FSEM, Procedia Environmental Sciences 33, 196 - 203, 2016

Webster dan Fasullo, (2003). Encyclopedia Atmospheri Science pp 1375-1376. 